JURNAL GEOGRAFI

Geografi dan Pengajarannya

ISSN 1412 - 6982

e-ISSN : 2443-3977

Volume XVIII Nomor 1 Juni 2020

\title{
MANFAAT PADANG LAMUN SEBAGAI PENYEIMBANG EKOSISTEM LAUT DI PULAU PRAMUKA, KEPULAUAN SERIBU
}

\author{
Muzani, Atika Ria Jayanti, Muhammad Wahyu Wardana, Nur Diana Sari, Yolanda \\ Lourentina Br.Ginting
}

Prodi Pendidikan Geografi, Universitas Negeri Jakarta

\begin{abstract}
Abstrak : Padang lamun terdapat di daerah perairan pesisir, dimana perairan pesisir merupakan lingkungan yang memperoleh sinar matahari cukup yang dapat menembus sampai ke dasar perairan serta kaya akan nutrien dari darat dan lautan. Karena lingkungan yang sangat mendukung ini maka tumbuhan lamun dapat hidup dan berkembang secara optimal. Ekosistem padang lamun juga mempunyai fungsi dan manfaat yang sangat penting bagi perairan wilayah pesisir. Padang Lamun (seagrass bed) termasuk kelompok angiospremae yang hidupnya di perairan dangkal serta terjadinya hubungan timbal balik antara komponen abiotik, tumbuhan dan hewan. Penelitian ini bertujuan untuk mengetahui manfaat padang lamun sebagai penyeimbang ekosistem laut di Pulau Pramuka, Kepulauan Seribu. Penelitian ini dilakukan dengan metode deskriptif dan pengamatan yang menghasilkan bahwa di Pulau Pramuka lamun sebagai ekosistem pesisir yang memiliki manfaat besar dalam menunjang sistem kehidupan dan berperan penting dalam dinamika pesisir dan laut, terutama perikanan, seperti sebagai tempat pembibitan, habitat tempat berlindung serta tempat ikan memperoleh makanan. Selain itu lamun juga mampu memperlambat arus sepanjang pantai dan menjadi perangkap sedimen bagi karang. Peran lamun dalam skala luas yaitu menjaga kestabilan $\mathrm{pH}$ air laut serta efektif menyerap $\mathrm{CO} 2$ dengan serapan sebesar $1.867 \mathrm{ton} / \mathrm{km} 2$ (48\%) relatif lebih tinggi dibandingkan bakau sebesar 806 ton/km2 (21\%) dan karang sebesar 1.197 ton/km2 (31\%) (Simamora, 2010). Karena perannya yang sangat kompleks, padang lamun dapat dikatakan sebagai salah satu ekosistem yang paling produktif di suatu perairan dan dikenal sebagai ekosistem laut yang penting (Fortes, 1990; Thangaradjon et al., 2007). Di Pulau Pramuka, Kepulauan Seribu padang lamun di jaga kelestarian melalui konservasi Taman Nasional Kepulauan Seribu. Padang Lamun di Pulau Pramuka sangat membantu dalam meyeimbangkan ekosistem laut.
\end{abstract}

Kata kunci: padang lamun, Pulau Pramuka, ekosistem laut, Kepulauan Seribu

\section{A. PENDAhuluan}

Secara astronomis, Kabupaten Administrasi Kepulauan Seribu terletak antara 5 terletak $5^{\circ} 10^{\prime} 00^{\prime \prime}$ sd $5^{\circ} 57^{\prime} 00^{\prime \prime}$ Lintang Selatan dan 106¹9'30', sd 106 44'50', Bujur Timur. Kepulauan Seribu dataran rendah dimana ketinggiannya ialah rata-rata 1 meter di atas permukaan laut. Kepulauan Seribu meempunyai tidak kurang 110 pulau. Berdasarkan posisi geografisnya, Kabupaten Administrasi Kepulauan Seribu memiliki batas-batas: di sebelah utara dengan Laut Jawa/ Selat Sunda; sebelah timur dengan Laut Jawa; sebelah selatan dengan Kota Adm. Jakarta Utara,

Alamat korespondensi : 
Kota Adm. Jakarta Barat dan Kabupaten

Tangerang; dan sebelah barat dengan Laut Jawa/ Selat Sunda.

Kecamatan Kepulauan Seribu Selatan membawahi tiga kelurahan yaitu Kelurahan Pulau Tidung, Kelurahan Pulau Pari, dan Kelurahan Pulau Untung Jawa. Kecamatan Kepulauan Seribu Utara membawahi tiga kelurahan juga yaitu Kelurahan Pulau Kelapa, Kelurahan Pulau Harapan, dan Kelurahan Pulau Panggang.Kepulauan Seribu yang terletak di Laut Jawa dan Teluk Jakarta merupakan suatu wilayah dengan karakteristik dan potensi alam yang berbeda dengan wilayah DKI Jakarta lainnya, sebab wilayah kepulauan seribu tersebut pada dasarnya adalah gugusan pulau-pulau terumbu karang yang terbentuk dan dibentuk oleh biota koral dan biota asosiasinya (algae, moluska, foraminifera dan lain-lain) dengan bantuan proses dinamika alam.

Pulau Pramuka masuk wilayah kabupaten administrasi Kepulauan Seribu terletak di sebelah utara teluk Jakarta. Lokasinya berada antara $06^{\circ} 00^{\prime} 40^{\prime \prime}$ dan $05^{\circ} 54^{\prime} 40^{\prime \prime} \quad$ Lintang Selatan dan $106^{\circ} 40^{\prime} 45^{\prime \prime}$ dan $109^{\circ} 01{ }^{\prime} 19^{\prime \prime}$ Bujur Timur. Total luas keseluruhan wilayah Kabupaten Administrasi Kepulauan Seribu luas daratan mencapai 897.71 Ha dan luas perairan Kepulauan
Seribu mencapai $6.997,50 \quad \mathrm{Km} 2$.

Topografi Kepulauan Seribu rata-rata landai. Berdasarkan Peraturan Pemerintah Nomor 55 Tahun 2001 tentang pembentukan kabupaten administrasi Kepulauan Seribu, secara resmi kepulauan seribu menjadi pemerintah kabupaten administrasi kepulauan Seribu, terpisah dari bagian kota Jakarta dengan pusat kabupaten berada di Pulau Pramuka. Luas Pulau Pramuka +/- $16 \mathrm{Ha}$, dengan peruntukan sebagai ibukota kabupaten \& pemukiman. Pulau Pramuka merupakan salah satu pulau yang memiliki wilayah pesisir yang dimana terdapat berbagai macam ekosistem peisisir di dalamya.

Wilayah pesisir merupakan pusat interaksi antara wilayah darat dengan wilayah perairan laut. Wilayah ini berperan sebagai penyangga, pelindung dan penyaring diantara wilayah daratan dan wilayah perairan laut. Komponen hayati dan nonhayati secara fungsional berhubungan antara satu dengan yang lainnya dan saling berinteraksi membentuk suatu sistem, yang dikenal dengan ekosistem. Apabila terjadi sesuatu yang mempengaruhi keseimbangan komponen penyusunnya, maka akan terjadi suatu masalah yang menggangu siklus ekosistem sehingga dapat mempengaruhi keseluruhan sistem 
yang ada, baik dalam kesatuan struktur fungsional maupun dalam keseimbangannya (Rochmady, 2010).

Ekosistem pesisir merupakan suatu bentukan ekosistem alamiah yang sangat produktif, mempunyai nilai ekologi serta nilai ekonomi yang tinggi. Ekosistem pesisir dapat menghasilkan bahan dasar untuk keperluan produksi serta pemenuhan pangan barang-barang rumah tangga. Selain fungsi ekonomi, ekosistem pesisir juga memiliki fungsi ekologi yang sangat penting bagi wilayah-wilayah yang berada disekitarnya, fungsi tersebut antara lain adalah sebagai penyedia nutrien, tempat bertelur, tumbuh dan berkembangnya ikan, dan tempat mencari makanan bagi beragam biota laut. Ekosistem pesisir memiliki peran sebagai pelindung pantai dari abrasi bagi wilayah daratan yang berada di belakang ekosistem ini Bengen dalam Rochmady,(2010).

Ekosistem wilayah pesisir pada umumnya terbentuk oleh tiga komponen yaitu mangrove, lamun, dan terumbu karang yang menjadikan wilayah pesisir menjadi wilayah yang relatif sangat subur. Ketiga komponen tersebut memiliki peranan masing-masing dalam menciptakan keseimbangan ekosistem wilayah pesisir. Ogden \& Gladfelter dalam Rochmady, (2010), ekosistem lamun bukan merupakan entitas yang terisolasi, tetapi berinteraksi dengan ekosistem lain disekitarnya. Interaksi terpenting ekosistem padang lamun adalah dengan ekosistem mangrove dan terumbu karang, dimana terdapat 5 tipe interaksi antara ketiga ekosistem tersebut: fisik, bahan organik terlarut, bahan organik partikel, migrasi fauna dan dampak manusia.

Di seluruh dunia terdapat 60 jenis lamun yang 20 jenisnya terdapat di wilayah Asia Tenggara. Di Indonesia sendiri terdapat 12 jenis lamun yang tersebar di hampir seluruh wilayah perairan Indonesia, dengan perkiraan luas mencapai $30.000 \mathrm{Km}^{2}$ (Nienhuis, 1993; Kuo, 2007) sedangkan terdapat 7 jenis lamun yang berada di wilayah Kawasan Taman Nasional Laut Kepulauan Seribu. (BTNKPS,2005).

Lamun merupakan suatu tumbuhan berbunga atau Angiospermae yang tumbuh dan berkembang dengan kondisi terendam dibawah permukaan air yang berada diperairan dangkal dengan kedalaman kurang dari 5 Meter saat pasang. Namun, terdapat beberapa jenis lamun yang dapat tumbuh pada kedalaman 5 sampai 90 Meter selama kondisi lingkungannya masih mendukung untuk pertumbuhan jenis lamun tersebut Duarte dalam Hutomo 
(2014) dan masih terjangkau oleh sinar matahari. Lamun umumnya ditemukan dengan bentuk berupa hamparan atau yang disebut dengan padang lamun. Hamparan lamun tersebut dapat berisi lebih dari satu jenis lamun. Padang lamun ini banyak ditemukan di daerah perairan tropis. Mc Roy dan Hefferich dalam Umar, (2010) berpendapat bahwa, padang lamun di daerah tropis merupakan ekosistem alam yang paling produktif.

Padang lamun merupakan salah satu ekosistem di wilayah pesisir yang mempunyai produktivitas tinggi dan mempunyai peranan yang penting dalam menciptakan kelestarian dan keanekaragaman organisme laut. Adi (2000) ; Chute et al. (2001) dan Helfman et al. (2009) padang lamun sebagai salah satu ekosistem laut dangkal di daerah pesisir mempunyai fungsi ekologis yang sangat penting sebagai daerah pemijahan dan asuhan bagi berbagai jenis orgnisme laut. Peranan penting lain dari padang lamun yaitu menjaga keseimbangan ekosistem laut. Seperti padang lamun sebagai pendaur ulang zat hara di perairan dimana bahan organik di kembalikan ke perairan melalui proses dekomposisi dengan bantuan aktivitas mikroorganisme.
Padang lamun merupakan ekosistem yang memiliki peran penting dalam menjaga keseimbangan ekosistem di perairan (Dahuri et al., 1996). Tingginya produktivitas primer di daerah padang lamun dan kemampuannya dalam meredam kekuatan arus dan gelombang membuat kawasan ini sangat menarik dan nyaman bagi kehidupan organisme perairan, baik sebagai tempat untuk mencari makan (feeding ground), tempat bertelur serta tumbuh dan berkembangnya ikan (spawning ground) ataupun tempat untuk pembesaran anak/larva/juvenil (nursery ground) (Danovaro et al., 2002). Selain itu ekosistem padang lamun juga berperan penting dalam menjaga produktivitas sumber daya perikanan dan kelestarian kekayaan alam di daerah pesisir. Untuk itu, ekosistem padang lamun perlu dijaga kelestariannya karena mempunyai peranan penting dalam menjaga keseimbangan ekosistem di perairan laut.

Ekosistem lamun sampai saat ini masih kurang mendapat perhatian, lain halnya dengan ekosistem-ekosistem lainnya seperti ekosistem terumbu karang, rumput laut dan mangrove, ekosistem lamun sampai saat ini masih kurang mendapat perhatian (Bengen, 2000). Hal ini dikarenakan kurangnya pengetahuan masyarakat mengenai 
fungsi dan manfaat dari adanya ekosistem lamun di wilayah mereka. Akibatnya, upaya masyarakat dalam menjaga kelestarian ekosistem ini masih sangat minim bahkan lamun dianggap sebagai tanaman pengganggu, sehingga akhirnya tanaman lamun tersebut diabaikan bahkan dimusnahkan padahal ekosistem lamun mempunyai peranan yang sangat penting dalam mendukung kehidupan serta perkembangan biota di laut yang hidup pada wilayah lamun. Lamun sendiri mempunyai peran sebagai produsen, penangkap sedimen, pendaur zat hara serta penjernih air.

Namun berbeda dengan kondisi masyarakat yang terdapat di Pulau Pramuka, mereka telah mengetahui manfaat serta fungsi dari lamun bagi kehidupan mereka. Di Pulau Pramuka padang lamun dijaga kelestariannya melalui Konservasi Taman Nasional Pulau Seribu.

Penelitian yang menitikberatkan topiknya mengenai fungsi serta manfaat keberadaan ekosistem lamun masih sangat sedikit diketahui oleh masyarakat luas, padahal kelestarian ekosistem lamun sudah semakin terancam keberadaannya. Oleh karena itu penelitian ini akan menitikberakan pada topik mengenai fungsi serta manfaat keberadaan ekosistem lamun di wilayah
Perairan Pulau Pramuka Kepulauan Seribu Penelitian ini berupaya menjabarkan betapa pentingnya ekosistem lamun ini bagi wilayah pesisir. Dengan mengetahui fungsi tersebut, diharapkan tidak hanya masyarakat kepulauan seribu saja yang tahu mengenai manfaat serta pentingnya lamun terhadap ekosistem, tetapi kepada seluruh masyarakat Indonesia maupun dunia agar kesadaran masyarakat dalam melestarikan ekosistem lamun semakin luas.

\section{B. METODOLOGI PENELITIAN}

\section{Lokasi dan Waktu Penelitian}

Penelitian ini dilakukan di perairan Pulau Pramuka, Kepulauan Seribu dengan posisi geografis dari 5'44'44" Lintang Selatan dan $106^{\circ} 36^{\prime} 49^{\prime \prime}$ Bujur Timur. Dilaksanakan pada tanggal 6-7 Desember 2019.

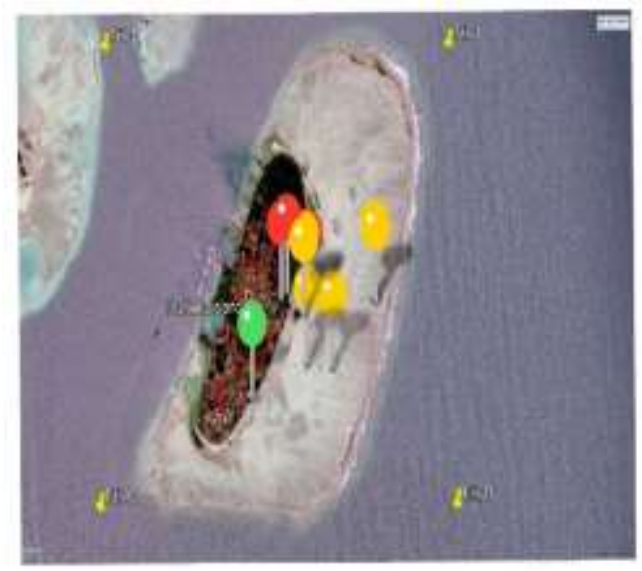

Gambar 1. Avenza Maps Pulau Pramuka. 


\section{Metode Pengumpulan Data}

Pengumpulan data menggunakan pengamatan visual kondisi padang lamun di bagian timur Pulau Pramuka yang mewakili kondisi keseluruhan padang lamun yang berada di seluruh penjuru Pulau Pramuka. Serta dengan metode pengamatan dan studi pustaka mengenai manfaat padang lamun. Dapat diketahui bahwa hampir di seluruh pesisir pantai Pulau Pramuka terdapat sebaran padang lamun, namun dalam penelitian ini di lihat kondisi padang lamun yang ada di bagian timur untuk mengetahui manfaat padang lamun sebagai penyeimbang ekosistem laut yang ada di daerah tersebut.

\section{HASIL DAN PEMBAHASAN}

Berdasarkan pengamatan yang dilakukan di dua titik bagian timur Pulau Pramuka Kepulauan Seribu, padang lamun (Seagrass bed) tumbuh dalam kelompok rumpun yang kecil-kecil dan tersebar tidak merata, namun kadang juga membentuk suatu padang luas dengan jenis homogen dan heterogen. Hal ini terkait dengan kondisi fisik perairan Kepulauan Seribu yang tidak stabil karena pengaruh arus dan gelombang. Keberadaan padang lamun di Taman Nasional Kepulauan Seribu dapat menstabilkan ekosistem, daun-daun lamun akan menangkap sedimen dan mengendapkannya ke dasar sehingga perairan menjadi jernih. (Tishmawati C.N dan Suryanti 2014)

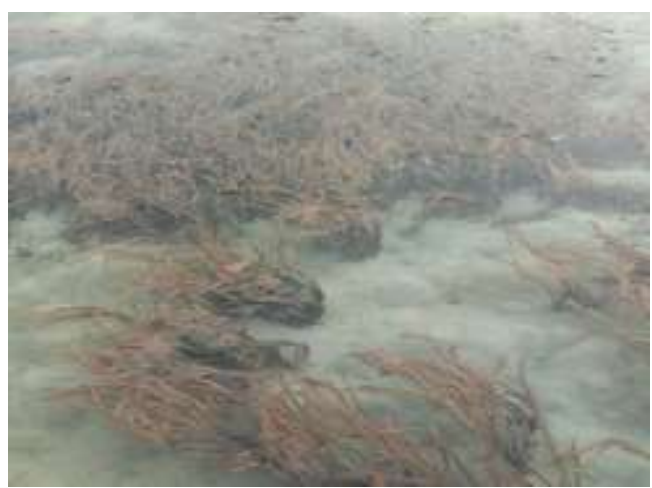

Gambar 2. Lamun Jenis Enhalus Acoroides.

Di seluruh dunia telah teridentifikasi 60 jenis lamun, 20 jenis diantaranya ditemukan di perairan Asia Tenggara dan terdapat 12 jenis lamun (7 genus) yang tumbuh di perairan Indonesia (Lee Long et al.2000; Hutomo et al., 1988; Fortes, 1988 dalam Dahuri,2003). Dari 12 jenis lamun yang teridentifikasi di Indonesia, 7 jenis diantaranya dapat ditemukan di kawasan Taman Nasional Laut Kepulauan Seribu (BTNKpS,2005). Ekosistem padang lamun bisa tumbuh subur di daerah yang berpasir dan berlumpur. (Fortes, M. D 1990). 


\section{Pasang Surut}

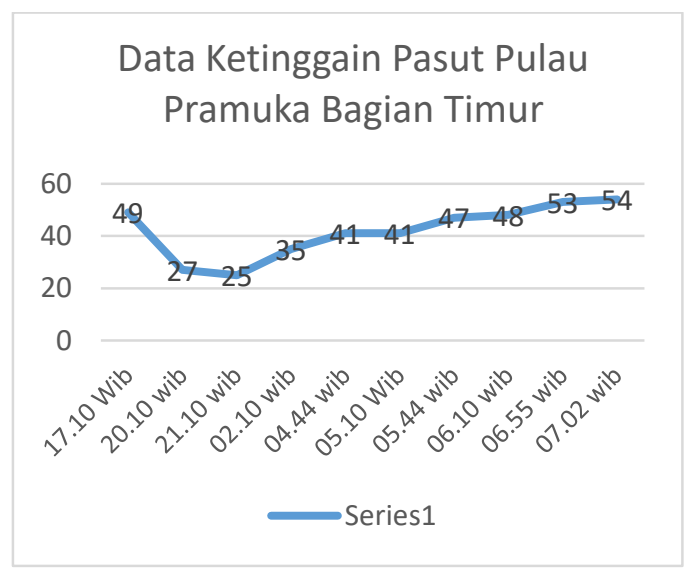

\section{Grafik Data Ketinggian Pasut Pulau Pramuka Bagian Timur}

Dan dari segi persebaran padang lamun bisa dipengaruhi oleh faktor pasang surut, dimana biji dari lamun akan terbawa oleh arus dan menyebar dari satu daerah ke daerah lain. Grafik tersebut adalah hasil dari pengukuran pasang surut menggunakan kayu ukur dari tanggal 07 Desember 2019 pukul 17:10 hingga 08 Desember 2019 pukul 07:10. Berdasarkan grafik terlihat bahwa tinggi maksimum pasang Pulau Pramuka mencapai $54 \mathrm{~cm}$, sedangkan surut terendah yakni pada $25 \mathrm{~cm}$. pada tanggal 08 Desember pukul 07:00 WIB

Tipe pasang surut pulau pramuka adalah Pasang Surut Harian Tunggal atau Diurnal Tide Mikrotidal, Dimana dalam satu hari tertentu terjadi segera setelah gelombang dan satu gelombang rendah. Periode pasang surut yang khas adalah 12 jam 24 menit dan kurang dari 2 meter.
Pasang surut yang terjadi di Pulau Pramuka dapat membantu lamun berkembang biak dengan baik.

\section{Suhu, Salinitas, Ph, Kecerahan dan Warna}

Suhu dapat mempengaruhi kehidupan padang lamun. Berdasarkan hasil pengukuran, suhu air laut di Pulau Pramuka yaitu $30^{\circ} \mathrm{C}$. Dengan suhu tersebut padang lamun dapat mempengaruhi proses pertumbuhan lamun seperti proses fotosintesis dan reproduksi. Perubahan suhu yang terjadi berpengaruh terhadap metabolisme, penyerapan unsur hara dan kelangsungan hidup lamun.

Tabel Data pH, Salinitas, Suhu, Kecerahan dan Warna di berbagai penjuru Pulau Pramuka

\begin{tabular}{lcccl}
\hline Wilayah & pH & Salinitas & Suhu & $\begin{array}{l}\text { Kecerahan } \\
\text { dan warna }\end{array}$ \\
\hline Utara & 6 & $30 \% \mathrm{ml}$ & $30^{\circ} \mathrm{C}$ & $\begin{array}{l}\text { Cerah dan } \\
\text { berwarna } \\
\text { biru gelap }\end{array}$ \\
Selatan & 7 & $30 \% \mathrm{ml}$ & $30^{\circ} \mathrm{C}$ & $\begin{array}{l}\text { Jernih dan } \\
\text { berwarna } \\
\text { biru }\end{array}$ \\
Barat & 7 & $25 \% \mathrm{ml}$ & $30^{\circ} \mathrm{C}$ & $\begin{array}{l}\text { Bening dan } \\
\text { berwarna } \\
\text { biru muda } \\
\text { Jernih dan } \\
\text { berwarna } \\
\text { hijau muda }\end{array}$ \\
Timur & 8 & $25 \% \mathrm{ml}$ & $30^{\circ} \mathrm{C}$ \\
\hline
\end{tabular}

Berdasarkan Keputusan Menteri Lingkungan Hidup Nomor 51 Tahun 2004 tentang Baku Mutu pH untuk pertumbuhan lamun berkisar antara 7- 
8,5. Sedangkan berdasarkan pengukuran pH yang dilakukan di berbagai penjuru Pulau Pramuka mendapatkan hasil berkisar antara 6-8. Di wilayah bagian utara memiliki pH 6 (asam) karena wilayah tersebut didominasi oleh hutan mangrove. Dan di wilayah ini juga lamun masih dapat tumbuh namun tidak dapat berkembang dengan baik.

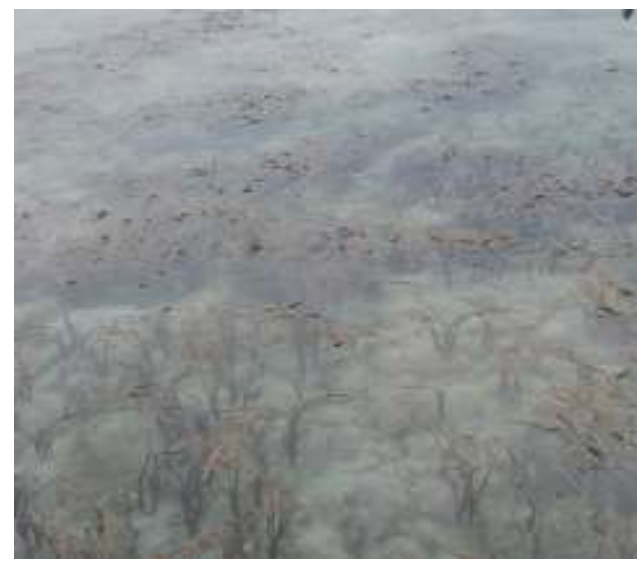

Gambar 3. Lamun dan Biota Laut.

Sedangkan di wilayah barat, selatan dan timur memiliki $\mathrm{pH}$ rata-rata 7 (netral) sehingga cocok untuk pertumbuhan dan perkembangbiakan lamun. Khususnya di wilayah timur terdapat konservasi lamun untuk melestarikan keberadaan lamun. Kemudian untuk salinitas air laut di Pulau Pramuka antara 25-30\%o $\mathrm{ml}$ dimana masih baik untuk pertumbuhan lamun. Salinitas juga mempengaruhi fisiologi lamun. Untuk kecerahan dan warna air laut di Pulau Pramuka keseluruhan cenderung cerah karena lamun berperan dengan baik dalam menyerap kotoran dan debu yang ada di perairan sepanjang Pulau Pramuka.

Selain beberapa faktor yang bisa mempengaruhi pesebaran, pertumbuhan, perkembangan dan kualitas, padang lamun juga memiliki beberapa manfaat diantaranya sebagai media untuk filtrasi atau menjernihkan perairan laut dangkal, dimana lamun berperan dalam menyaring debu-debu yang terdapat di permukaan air laut. padang lamun juga bisa dijadikan sebagai tempat tinggal berbagai biota laut, termasuk biota laut yang bernilai ekonomis, seperti ikan baronang/lingkis, ikan cendro, rajungan atau kepiting, teripang dan lain-lain. Keberadaan biota tersebut bermanfaat bagi manusia sebagai sumber bahan makanan. Tidak hanya itu padang lamun juga bermanfaat sebagai tempat pemeliharaan anakan berbagai jenis biota laut. Dan saat ikan tersebut sudah dewasa, maka akan berimigrasi. (Adrim, Mohammad 2006). Manfaat lainnya yaitu sebagai tempat mencari makanan bagi berbagai macam biota laut, terutama ikan cendro dan penyu yang hampir punah, mengurangi besarnya energi gelombang di pantai dan berperan sebagai penstabil sedimen sehingga mampu mencegah erosi di pesisir pantai dan berperan dalam Berperan dalam mitigasi dan adaptasi 
perubahan iklim. (Djunaedi, A.,

Hariyadi, dan Mujiyanto 2012).

Ekosistem lamun juga mempunyai

peranan penting dalam menunjang

kehidupan dan perkembangan jasad

hidup di laut dangkal, diantaranya adalah:

\section{Sebagai Produsen Primer}

Tingkat produktivitas primer lamun sangatlah tinggi bila dibandingkan dengan ekosistem lainnya yang ada di laut dangkal seperti ekosistem terumbu karang. Dan jika faktor lingkungan mendukung maka lamun akan berkembang dan tumbuh dengan cepat. (Thayer et al, 1975)

\section{Sebagai Habitat Biota}

Berbagai hewan dan tumbuhtumbuhan seperti alga hidup di tempat yang menurut mereka memberikan perlindungan dan dapat dijadikan tempat menempel seperti lamun. Disamping itu, padang lamun atau biasa disebut seagrass beds dapat juga sebagai daerah asuhan, padang pengembalaan dan makan dari berbagai jenis ikan herbivora dan coral fish. Padang lamun banyak ditempeli biota yang bisa menjadi makanan ikanikan. Selain itu padang lamun juga bisa dijadikan tempat perlindungan ikan-ikan. (Kikuchi \& Peres, 1977).

\section{Sebagai Penangkap Sedimen}

Daun lamun yang lebat akan memperlambat air yang disebabkan oleh arus dan ombak, sehingga perairan di sekitarnya menjadi tenang. Selain itu akar padang lamun juga dapat menahan dan mengikat sedimen, sehingga dapat menguatkan dan menstabilkan dasar permukaan. Jadi, padang lamun selain berfungsi sebagai penangkap sedimen juga dapat mencegah erosi. Karena pergerakan ombak sedimen yang terbawa ke pinggir akan ditahan oleh lamun, dan hal tersebut akan memperkuat permukaan. (Gingsburg \& Lowestan, 1958).

\section{Sebagai Pendaur Zat Hara}

Padang lamun memang memegang peran penting dalam pendauran berbagai zat hara dan elemenelemen yang langka di lingkungan laut khususnya zat-zat hara yang dibutuhkan oleh alga. Ekosistem lamun perairan dangkal mempunyai fungsi antara lain (Philips \& Menez, 1988):

- Menstabilakan dan menahan sedimensedimen yang dibawa melalui tekanan yang satu ke tekanan yang lain dari arus dan gelombang.

- Daun-daun padang lamun memperlambat dan mengurangi arus dan gelombang serta mengembangkan sedimentasi. 
- Memberikan perlindungan terhadap hewan-hewan muda dan dewasa yang berkunjung ke padang lamun.

- Daun-daunnya sangat membantu organisme-organisme.

- Mempunyai produktivitas dan pertumbuhan yang tinggi.

- Memfiksasi karbon yang sebagian besar masuk ke dalam sistem daur rantai makanan. (Tangke, Umar 2010)

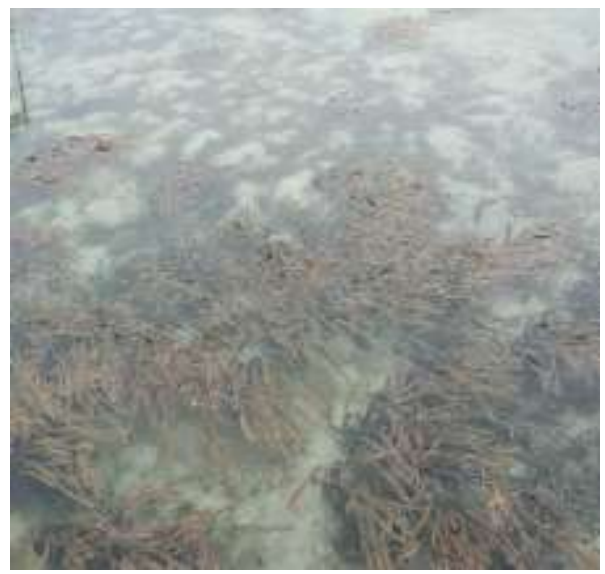

Gambar 4. Lamun

Lamun juga berperan sebagai komoditi yang sudah banyak dimanfaatkan oleh masyarakat baik secara tradisional maupun secara modern (Philips \& Menez, 1988). Seperti untuk penyaring limbah, stabilitator pantai, dan obat-obatan. Padang lamun juga membentuk suatu komunitas yang merupakan habitat bagi berbagai jenis hewan laut. Komunitas lamun ini juga dapat memperlambat gerakan air, bahkan ada juga jenis lamun yang dapat dikonsumsi bagi penduduk sekitar pantai. (Tangke, Umar 2010)
Keberadaan ekosistem padang lamun masih belum banyak dikenal para masyarakat umum maupun akademisi, jika dibandingkan dengan ekosistem lain seperti terumbu karang dan mangrove. Meskipun diantara ekosistem-ekosistem tersebut di kawasan pesisir merupakan satu kesatuan sistem dalam menjalankan fungsi ekologisnya. Secara ekonomi lamun digunakan sebagai bahan dasar kerajinan, bahan pembuatan kertas, dan obat-obatan. Selain itu, padang lamun juga berfungsi sebagai daerah tangkapan ikan, karena keberadaan lamun di suatu perairan laut menjadi penyedia nutrisi bagi ikan, sehingga meningkatkan produktivitas ikan. (Tangke, Umar 2010)

Namun tidak seperti ekosistem terumbu karang, rumput laut dan mangrove, ekosistem lamun sampai saat ini masih kurang mendapat perhatian (Bengen, 2000). Hal ini dikarenakan banyaknya masyarakat yang belum mengetahui tentang fungsi ekosistem lamun dan dapat mengambil manfaat langsung dari lamun. Akibatnya, upaya masyarakat dalam menjaga kelestarian ekosistem ini sangat minim bahkan terkadang dianggap sebagai tanaman pengganggu, sehingga akhirnya diabaikan atau dimusnahkan. Secara umum, kerusakan ekosistem lamun diduga disebabkan oleh faktor alami dan aktivitas manusia. Faktor alami yang 
menjadi ancaman terhadap ekosistem lamun yaitu abrasi akibat gelombang pantai dan sedimentasi. Sedangkan faktor lainnya yaitu aktivitas manusia. Salah satunya yaitu aktivitas lalu lintas perahu nelayan dan aktifitas masyarakat nelayan yang sering memanfaatkan padang lamun sebagai tempat mencari ikan diduga dapat mempengaruhi kondisi padang lamun di lokasi tersebut. Hal ini sesuai dengan tekanan yang sering dialami oleh ekosistem padang lamun adalah adanya aktifitas masyarakat pesisir yang banyak menfaatkan padang lamun sebagai tempat menangkap ikan dan sebagai jalur lalu lintas kapal nelayan. (Tomascick et al. 1997) Beberapa faktor lainnya yang mempengaruhi kerusakan lamun antara lain pencemaran limbah industri, limbah pertanian, sedimentasi, pembuangan sampah organik cair, pengerukan pasir dan reklamasi pantai serta pembabatan secara langsung (Dahuri 1993).

Kerusakan pada ekosistem
lamun bisa mengakibatkan kerusakan
atau berkurangnya tutupan terumbu karang. Hal ini bisa berakibat kepada kesehatan ekosistem terumbu karang. Apabila ekosistem padang lamun rusak, tidak ada penyaring sedimen untuk ekosistem terumbu karang. Selain itu, transfer materi pun bisa terganggu. Oleh karena itu, ekosistem lamun pun menjadi salah satu elemen penting dan penyeimbang ekosistem perairan. Tidak hanya berguna bagi hewan laut yang hidup disekitarnya namun juga berguna bagi tumbuhan disekitanya juga. Apabila terjadi kerusakan padang lamun pasti akan berdampak pada masyarakat terutama yang tinggal di kawasan pesisir. Dampak negatifnya seperti beralihnya mata pencaharian masyarakat yang awalnya berprofesi sebagai pencari kerang dan nelayan pinggiran (nelayan bondet) menjadi nelayan tengah, karyawan pabrik, pencari keong sawah, dan pedagang akibat dari berkurangnya jumlah ikan. Perubahan tersebut mengakibatkan penghasilan masyarakat pesisir semakin berkurang. Dan juga akan berdampak kelangsungan biotabiota laut yang hidup di ekosistem lamun. (Tangke, Umar 2010).

Maka dari itu perlunya mencegah kerusakan ekosistem padang lamun yaitu dengan melakukan sosialisasi kepada masyarakat tentang fungsi-fungsi ekosistem lamun. Hal itu perlu dilakukan secara rutin guna menimbulkan rasa peduli, memiliki, dan tanggung jawab antar warga pesisir maupun warga Banten terkait pelestarian dan keberlangsungan ekosistem lamun, sehingga ekosistem tersebut tidak hanya dapat dimanfaatkan untuk saat ini saja, tetapi juga untuk generasi di masa depan. 
Selain itu juga dilakukan implementasi terkait pelestarian populasi lamun, seperti pelaksanaan kegiatan aksi bersihbersih lingkungan pesisir untuk menjaga mutu dan kualitas lingkungan. Dalam hal ini tidak hanya masyarakat pesisir saja, akan tetapi perlunya partisipasi aktif dari seluruh warga seperti melakukan pengelolaan dan pengolahan limbah baik limbah padat (sampah) maupun limbah cair agar tidak ikut terbawa ke dalam perairan dengan cara pembuatan dan pengelolaan IPAL off site atau secara terpusat dan penerapan 3R (Reduce, Reuse, dan Recycle) dalam pengelolaah sampahnya guna meminimalisir timbulnya dampak secara langsung bagi lamun. Kemudian menginsentifkan kegiatan pengawasan terhadap ekosistem lamun dan daerah pesisir sekitarnya. Dalam hal ini perlu adanya kerjasama antar pemerintah, swasta, dan masyarakat dalam mengawasi seluruh kegiatan, khususnya yang langsung berdampak pada lingkungan pesisir. Selain itu perlunya penegakan aturan dan sanksi yang tegas bagi para perusak ekosistem, khususnya lamun. Tidak hanya itu, untuk mencegah timbulnya dampak lingkungan maka perlu melakukan penyusunan AMDAL (Analisis Mengenai Dampak Lingkungan). Dengan demikian diharapkan dapat menjaga kelestarian dan keberlangsungan ekosistem padang lamun. Dan pastinya dilakukan konservasi yang mana sudah dilakukan di Pulau Pramuka, Kepulauan Seribu ini di Taman Nasional Kepulauan Seribu. (Tangke, Umar 2010)

\section{KESIMPULAN}

Keberadaan Padang Lamun di Pulau Pramuka, Kepulauan Seribu memiliki peran yang sangat penting dalam menjaga keseimbangan ekosistem. Manfaat Padang Lamun diantaranya adalah sebagai media untuk filtrasi atau menjernihkan perairan laut dangkal, dimana lamun berperan dalam menyaring debu-debu yang terdapat di permukaan air laut. Padang lamun berfungsi sebagai tempat tinggal berbagai biota laut, termasuk biota laut yang bernilai ekonomis, seperti ikan baronang/lingkis, ikan cendro, rajungan atau kepiting, teripang dan lain-lain. Keberadaan biota tersebut bermanfaat bagi manusia sebagai sumber bahan makanan. Manfaat lainnya yaitu sebagai tempat mencari makanan bagi berbagai macam biota laut, terutama ikan cendro dan penyu yang hampir punah, mengurangi besarnya energi gelombang di pantai dan berperan sebagai penstabil sedimen sehingga mampu mencegah erosi di pesisir pantai dan berperan dalam Berperan dalam mitigasi dan adaptasi perubahan iklim. 
Ekosistem lamun juga mempunyai peranan penting dalam menunjang kehidupan dan perkembangan jasad hidup di laut dangkal, Tetapi keberadaan padang juga dapat rusak. Kerusakan padang lamun dapat disebabkan oleh faktor alam dan manusia.

Sayangnya, keberadaan ekosistem padang lamun masih belum banyak dikenal oleh masyarakat umum maupun akademisi, jika dibandingkan dengan ekosistem lain seperti terumbu karang dan mangrove. Padang Lamun seringkali dianggap sebagai tanaman pengganggu, sehingga akhirnya diabaikan atau dimusnahkan. Namun dengan adanya Taman Nasional Kepulauan Seribu di Pulau Pramuka sebagai salah satu tempat konservasi padang lamun dapat mengedukasi masyarakat setempat dan masyarakat umum yang dating ke Pulau Pramuka sehingga pengetahuan masyarakat dapat bertambah dan keberadaan ekosistem Padang Lamun pun terjaga kelestariannya.

\section{DAFTAR PUSTAKA}

Adrim, Mohammad. 2006. Asosiasi Ikan di Padang Lamun. Jurnal Oceana. 31(4): 1-7

Azizah, E., Nasution, S. \& Ghalib, M. 2017. Biomass and Diversityof Seagrass Enhalus Acoroides in The Vilage Waers Jago Jago of Tapanuli Tengan North Sumatra
Province. Jurnal Online Mahasiswa Fakultas Perikanan dan Ilmu Kelautan Universitas Riau, 4(2): 1-10.

Christen, C., Djunaedi, O. S., \& Purba, N. P. 2012. Pengaruh Tinggi Pasang Surut Terhadap Pertumbuhan dan Biomassa Daun Lamun Enhalus Acoroides di Pulau Pari Kepulauan Seribu Jakarta. Jurnal Perikanan Kelautan. 3(3): 287-294

Coles, R. G. L. W. J. Long, J. E. Mellors, J. M. Bibby, and Roelofs. 1998. Seagrass Meadows of the Eastern Gulf of Carpentaria. QDPI Information Series.

Dennison, W. C., R. J. Orth, K. A. Moore, J. C. Stevenson, V. Carter, S.Kollar, P.W. Bergstrom, and Batiuk, R.A. 1993. Assesing Water Quality with Submersed Aquatic Vegetation: Habitat Requirements as Barometers of Chesapeake Bay health. Bio-Science. 42(2): 86-94.

Djunaedi, A., Hariyadi, Dan Mujiyanto. 2012. Struktur Komunitas Padang Lamun Di Perairan Pulau Kumbang, Kepulauan Karimunjawa. Ilmu Kelautan. 17 (4): 217-225

Dore, I., and C. Frimodt. 1987. An illustrated guide to shrimp of the world. OspreyBooks, Huntington, N.Y. 229 pp.

English, S., C. Wilkinson dan V. Baker. 1994. Survey Manual for Tropical Marine Resources. ASEAN Australia Marine Science Project: Living Coastal Resources.

Erftemeijer, P. L. A. 1994. Differences in Nutrient Concentration and Resources between Seagrass Communities on Carbonate and Terrigenous Sediments in South Sulawesi, Indonesia. Bulletin of Marine Science. 54(2): 403-419. 
Fortes, M. D. 1990. Seagrasses: A Resource Unknown in the ASEAN Region. Association of Southeast Asian Nations/United States Coastal Resources Management Project Education Series 6.

Gulland, J. A. and J. R. Brian (Editor). 1984. Penaeid Shrimps-their Biology and Management. Selected papers presented at the workshop on the scientific basis for the management of penaeid shrimp held at Key West, Florida, U.S.A. Fishing News Books Limited.

Iftinaan. A., Doni J., M. Untung dan Wahyuniar. 2017. Potensi Sumberdaya Lamun sebagai Penunjang Ekowisata Di Pulau Menjangan Besar, Kepulauan Karimun Jawa. Jurnal Perikanan dan Kelautan. 8(2): 43-49

Indriani, Aan, dan Defri Y. 2017. Cadangan Karbon di Area Padang Lamun Pesisir Pulau Bintan, Kepulauan Riau. Oseanologi dan Limnologi di Indonesia. 2(3): 1-11

Malikusworo, Hutomo dan Nontji, Anugrah.2014. Panduan
Monitoring Padang Lamun. Jakarta. Lipi

Riniatsih, I., dan Munasik. 2017. Keanekaragaman Megabentos yang Berasosiasi di Ekosistem Padang Lamun Perairan Wailiti, Maumere Kabupaten Sikka, Nusa Tenggara Timur. Jurnal Kelautan Tropis. 20(1): 55-59

Rochmady, 2010. Rehabilitasi Ekosistem Padang Lamun. Makassar. Universitas Hasanuddin.

Supriyadi, I.H., Ricky R., dan Marindah Y.I. 2018. Dampak Perubahan Penggunaan Lahan Terhadap Kondisi Padang Lamun Di Perairan Timur Pulau Bintan Kepulauan Riau. Jurnal Segara. 14(1): $1-10$

Tangke, Umar. 2010. Ekosistem Padang Lamun. Jurnal Ilmiah agribisnis dan Perikanan. 3(1): 1-8

Tishmawati, C.N \& Suryanti., Ain C (2014). Hubungan Kerapatan Lamun (Seagrass ) dengan kelimpahan Syngnathide di Pulau Panggang Kepulauan Seribu. Management of Aquatic Resources Journal. 3(4): 147-153 